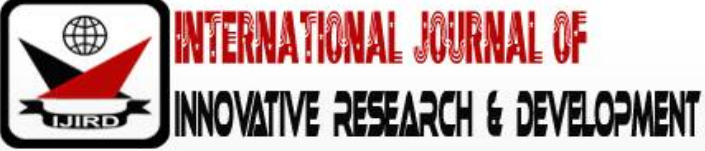

ISSN 2278 - 0211 (Online)

\section{The Use of Computer Technology by Visual Arts Teachers and Students in Public Senior High Schools in the Cape Coast Metropolis, Ghana}

\author{
Dr. Faustina Kwakye \\ Dean, School of Business, West End University College, Ghana \\ Alfred Ghartey \\ Assistant Registrar, Centre for International Education, University of Cape Coast, Ghana
}

\begin{abstract}
:
The study utilized the quantitative method to examine resources, available software, attitudes and challenges of teachers and learners in using computer technology in 10Senior High Schools within the Cape Coast Metropolis. The lottery method was used to select, collect data from 20 out of 40 teachers and 150 out of 300 students through self-administered, close-ended questionnaires. Descriptive analysis was carried out using tables of frequencies and percentages. Among the findings were inadequate and obsolete computers hampering regular access required for proper training. The commonest software was Microsoft Office. Adobe Photoshop, Adobe Illustrator, CorelDraw which are important for teaching and learning Visual Arts were available in very few schools. School authorities, parents, Ministry of Education and NGOs should assist in supplying the schools with new computers and relevant software. Curriculum planners should increase teaching periods to improve regularity of computer use.
\end{abstract}

Keywords: Visual arts, computer technology, attitude, hardware, software

\section{Introduction}

Traditional approaches to teaching and learning of Visual Arts have been challenged by new and innovative approaches based on the latest advances in computer and information technology. During the last few years, computer technology has been adopted in many areas such as business, entertainment, governance and education across the world. The global adoption of computers has been the landmark on the educational scene for the last few years (Albirini, 2006). Harvey (1993) envisaged that the effectiveness of the use of computers in education may be an important factor in determining which countries will succeed in the future. The vast resources and opportunities that computers and internet provide have brought about new tools, approaches and strategies in graphic design teaching and learning.

The integration of computer technology has become a high priority across many schools in the world. The interest in and importance given to the role of Visual Arts or vocational skills in national development have grown rapidly in recent years. Several researches suggest that ICT will be an important part of education for the next generation too (Bransford, Brown\& Cocking, 2000; Grimus, 2000; Yelland, 2001). The results of these studies have revealed the need for a systematic and principled approach to the integration of technology into the teaching and learning of Visual Arts in the classroom.

From Wikipedia, the importance of ICT in Visual Artsin cludes the fact that ICT helps to scan drawings and photographs, to manipulate images, make printouts for a project work, collect secondary source materials, and to search for contemporary work on sculpture, and then use digital photography and image manipulation software. Again, ICT helps to scan and record drawings and sketchbook to develop ideas and letterforms. Coreld raw, important and very vital software in Visual Arts, is a vector drawing tool used to create logos, signs, etc. Photoshop software allows users to edit graphic designers and photographers to enhance, manipulate and improve images. This makes it important that an effective integration of technology is achieved when students are able to select technology tools to help them obtain information in a timely manner, analyze and synthesize the information and present it professionally. Training designers to implement solutions via the computer has become expected by the graphic design industry, which has been radically modified in the past five years.

According to Tesfay (2008), the ultimate goal of introducing ICT in the education system is to use ICT as a tool in the teaching and learning process across all subject areas of the national curriculum to improve quality of education. Although the ICT in education policy for Ghana had a long gestation period (GOG, 2003), the Government of Ghana placed a strong emphasis on the role of ICT in education by the end of the first quarter of 2007. The policy implementation saw the provision of computer laboratories for all major public universities, all secondary schools as well as some basic schools, aimed at tapping into the benefits ICT offers in the area of teaching and learning. 
In the last few years, educational policy makers, non-governmental organizations (NGO), bilateral and multilateral donor organizations, and school administrators are making the collective efforts to promote ICT in Ghanaian secondary schools. Cape Coast has a lot of reputable second cycle institutions and so it is often assumed that they will have a number of computers for the students to use in their Visual Arts classes.

\subsection{Statement of the Problem}

It is evident that educational policy makers, non-governmental organizations (NGOs), bilateral and multilateral donor organizations, and school administrators are making the collective effort to promote ICT in Ghanaian secondary schools. Form observation, students enrolled in premier schools in Accra, Cape Coast and Kumasi and those in other urban areas who have easy access to computers and internet cafes have already made a considerable increase in the use of computers and the internet. Because of the efforts of NGOs and donor organizations in particular, ICT facilities have extended to some schools, mostly in urban communities (Dankwa, 1997; Parthemore, 2003).

The use of Information Communication Technology (ICTs) in Ghanaian schools and African countries is generally increasing and dramatically growing (Tella, 2007). However, while there is a great deal of knowledge about how ICTs are being diffused and used in high schools in developed countries, there is not much information on how ICTs are being diffused and used by teachers in Ghanaian schools. People have attributed the situation to several issues including lack of adequate facilities and training, which tend to hamper the continued progress of developing this sophisticated computer technology application in teaching and learning.

Despite the inherent advantages of the ICT in teaching and for socialization, the extent to which it has benefited Visual Arts teachers and students in attaining teaching and learning effectiveness and desired change in the output of the works produced stands to be questioned.

A casual observation and comments from both lecturers and student teachers who participate in the off-campus teaching practice exercise programme in Senior High Schools (SHS) in Cape Coast and other parts of the country indicate that the majority SHS students and teachers did not have access to the computers in their schools. The few teachers and students who sometimes had access to the computers consistently used them for playing music, watching movies and playing games. In view of the observations and comments, one keeps wondering whether the current computer technologies in Ghanaian Senior High Schools are of any relevance to teaching and learning, in particular, the Visual Arts teachers and students.

It is against this backdrop that an investigation into computer technology used by teachers and students in some selected Ghanaian Senior High schools in the Cape Coast Metropolis was considered very relevant.

\subsection{Objectives}

The main objective is to examine the use of Computer Technology in the teaching and learning of Visual Arts in public senior high schools in the Cape Coast metropolis.

Specifically, the study sought to:

- Find Out The Computer Technology Facilities Available In The Selected Schools;

- Examine The Attitude Of Visual Arts Teachers And Students Towards Computer Technology;

- Investigate The Challenges Encountered By Teachers And Students In The Use Of Computer Technology In The Leaching And Learning Of Visual Arts.

\subsection{Significance of the Study}

The government and other stakeholders concerned with teaching and learning of Visual Arts could also use the information to help address the inadequacy of the computer facilities available in the schools. The result of this study extends current scanty knowledge on the use of computer technology in Visual Arts. The study provides a platform for a more detailed research in the area of computer integration in education in Ghana. The choice of ICT and Visual Arts education also stems from the fact that the tools and techniques available for Visual Arts expression have expanded tremendously with the advent of new hardware and software, and ICT provides unique opportunities to extend Visual Arts teaching and learning.

\section{Literature Review}

\subsection{Visual Art Teacher's Attitudes towards Computer Technology Use}

Visual Arts teachers' traditional ideologies concerning the framework of aesthetics, and their beliefs about the incompatibility between technology and art itself, have been identified as barriers to the adoption of ICT (Matthew, Callaway, Letendre, Kimbell-Lopez., \& Stephens (2002); Wood, 2004). Previous studies have indicated that some art teachers view ICT as gimmicky and easily misused, and some fear loss of student creativity (Crowe, 1988) and a focus on replication of art (Rogers, 1995). Interestingly, Taylor (1999) noted that photography in its early history faced similar resistance when debate ensued as to whether it should be considered an art form. Additionally, Loveless (2003) documented instances where teachers felt that the school network was set up on a 'business model', which was not helpful in the context of an 'art space'. Wang (2002) reported continued reluctance on the part of Visual Arts teachers to embrace new technologies. Bamford (2001) referred to a study of accomplished art teachers and quality art education within which no mention was made of the inclusion of ICT.

While some resistance to integration might be attributable to age, research cited in Delacruz (2004) suggested that although many art teachers use more ICT, only basic applications, such as word processing are mostly used rather 
than applications designed to support creativity. Wood's (2004) work highlighted that, while some teachers believe technology maintains student engagement and provides inspiration, others were concerned that students could be easily distracted by technology.

Although teachers today recognize the importance of integrating technology into their instruction and course syllabi, successful implementation is often impeded by both external barriers (Ertmer, Addison, Lane, Ross \& Woods, 1999). The external barriers to computer technology integration are also referred to as environmental factors or first order barriers and these are: lack of access to computers and software, insufficient time to plan, and inadequate technical and administrative support and training. Other examples include: no support from the administration, lack of resources, unavailability of supportive staff, and a lack of effective training. Internal barriers are also called social cognitive factors, or second order barriers, which include: teachers' beliefs about teaching and computers, teachers' established classroom practices and unwillingness to change, lack of relevance of computer technology resources in teaching, and lack of selfconfidence. Additional examples include personal and behavioural factors of attitude and anxiety, self-efficacy, willingness to make a time commitment and take personal risk, computer competency and beliefs and knowledge about and perceived relevance of computers (Dusick, 1998). Resource constraints have also been recognized as barriers by a number of writers including Henning (2000), Wang (2002) and Delacruz (2004). These authors also identified poor training opportunities, lack of support and lack of time as significant impacts on Visual Arts teachers' willingness to integrate ICT

Ottesen (2006) revealed in his study that one fundamental problem facing efficient ICT integration in schools is the lack of computer infrastructure and appropriate access, and he revealed a substantive correlation between technology access and use. In another study, Yildirim (2007) found the following: teachers agreed that access to ICT infrastructure is one of the effective means to integrate ICT in classrooms and that education and employment are key building blocks of strategies to eradicate poverty.

\subsection{Factors That Hinder Diffusion of Icts in Schools}

There are many factors identified as hindrances to the use of ICTs in high schools. Pelgrum (2001) presented a list of 10 such factors that impede ICT integration in schools. Out of the 10, four major ones which were identified were: Personal ideas about the contribution that technology can make to the processes of teaching and learning and classroom management; teachers' lack of knowledge and skills; insufficient number of computers and ICT infrastructure; and difficulty in integrating ICTs instruction in classrooms. In related a study, Ely (1993) similarly distinguished three major conditions, relevant to ICT integration in classrooms, these are: Dissatisfaction with the status quo, existence of knowledge and skills, and availability of innovative technology in their classrooms. In the study, it was also reported that the most important reason teachers give for not using ICT is that they were not familiar with ICT or they feel unsure about it. According to Mooij and Smeets (2001), school managers' policies and budgetary decisions and in general the attitudes of the school managers (their commitment and decisions) are expected to be relevant to the ICT innovation process.

\subsection{Materials and Method}

The quantitative approach was used for this research. It was restricted to schools that offered Visual Arts and also who had up to three levels, i.e. first, second and third years and these were 10 out of 11 Senior High Schools. In view of this, the whole census of schools offering Visual Arts programme was involved in the study. For the purposes of anonymity, the names of schools which participated in the study are designated as SHS A to SHS K. The lottery method, a simple random sampling technique was employed to select the sample sizes, which involved writing names of the target population on pieces of papers and picking them after mixing the papers. The method gave equal and fair representation to every member of the population. In the case of the teachers, in two schools the sample sizes did not represent $50 \%$ because if the fact that there could not be 1.5 people and taking the next whole numbers would have exceeded 20 . The schools and respondents who participated in the study are presented in Table 1.

The lottery method was used to select and collect descriptive survey data collection was research design. A descriptive survey has the merits of producing more information about the present conditions and present needs which were characteristics of the research problem (Fraenkel\&Wallen, 2006). The study conditions that might exist were described by recording, analyzing and interpreting data according to research questions generated in the study.

\subsection{Population, Sample and Sampling Technique}

The total number of teachers in the lists complied from the 10 selected public high schools in the Cape Coast Metropolis was 40 and the students were 300. Half (50.0\%) of the total population of both teachers and students were selected from each of the 10 schools to participate in the study based on Amedahe (2002), who contended thatwhen the population of study is high in proportion, a sample size of $30 \%$ or higher is appropriate for representation and generalization.

The names of the target population on pieces of papers and picking them after mixing the papers (lottery method) was used to select 20 Visual Arts teachers and 150 students, making it a total of 170. The method gave equal and fair representation to every member of the population. In the case of the teachers, the sample sizes did not represent $50 \%$ in all cases owing to the approximation of fractions (See Table 1). 


\begin{tabular}{|c|c|c|c|c|}
\hline $\begin{array}{c}\text { Designation } \\
\text { of School }\end{array}$ & $\begin{array}{c}\text { Total No. } \\
\text { of Teachers }\end{array}$ & $\begin{array}{c}\text { Number } \\
\text { Selected }\end{array}$ & $\begin{array}{c}\text { Total No. } \\
\text { of students }\end{array}$ & $\begin{array}{c}\text { Number } \\
\text { Selected }\end{array}$ \\
\hline SHSA & 4 & 2 & 37 & 18 \\
\hline SHSB & 5 & 3 & 36 & 18 \\
\hline SHSC & 4 & 2 & 35 & 17 \\
\hline SHSE & 4 & 2 & 34 & 17 \\
\hline SHSF & 5 & 3 & 33 & 16 \\
\hline SHSG & 4 & 2 & 32 & 16 \\
\hline SHSH & 4 & 2 & 27 & 14 \\
\hline SHS & 4 & 2 & 25 & 13 \\
\hline SHSJ & 3 & 1 & 23 & 12 \\
\hline SHS & 3 & 1 & 18 & 9 \\
\hline Total & 40 & 20 & 300 & 150 \\
\hline
\end{tabular}

Table 1: Population and Sample of Respondents

Source: Field Survey, 2014

\section{Results}

\subsection{Demographic Data}

Preliminary information elicited from the teachers and students included their schools, highest educational qualification, number of Visual Arts teachers on staff, type of school, age, sex, number of years of teaching Visual Arts and the number of years of computer usage. Data obtained are presented in Tables 2 and 3 and the discussion follows each table.

\begin{tabular}{|c|c|c|}
\hline Age of Teachers (in Years) (n = 20) & No. & \% \\
\hline $20-25$ & 4 & 20.0 \\
\hline $26-30$ & 3 & 15.0 \\
\hline $31-35$ & 4 & 20.0 \\
\hline $36-40$ & 4 & 20.0 \\
\hline $41-45$ & 2 & 10.0 \\
\hline Above 46 & 3 & 15.0 \\
\hline \multicolumn{2}{|c|}{ Age of Students (n=150) } \\
\hline $13-15$ & 1 & 0.7 \\
$16-18$ & 116 & 77.3 \\
Above 18 & 33 & 22.0 \\
\hline
\end{tabular}

Table 2: Age Range of Teachers and Students

Source: Field Survey, 2014

Table 2 gives a picture of mixed ages of Visual Arts teachers in the Cape Coast Metropolis. While four (20.0\%) of them were aged between 20 and 25 years, another four (20.0\%) were also aged above 46 years. Three (15.0\%) were aged between 26 and 30 years, and the remaining two (10.0\%) were aged between 41 and 45.

\subsection{Resources/ Facilities Available in the Schools for Computer Use}

Ottesen (2006) revealed that one of the fundamental problems facing ICT integration in schools' concerns lack of facilities coupled with inadequate number of computers. This section therefore concentrates on the number and software available on the computers in the schools for the respondents to use.

\begin{tabular}{|c|c|c|c|c|cc|}
\hline \multirow{2}{*}{$\begin{array}{c}\text { No. of } \\
\text { Computers }\end{array}$} & \multicolumn{2}{|c|}{ Teachers } & \multicolumn{2}{c|}{ Students } & \multicolumn{2}{c|}{ Total } \\
\cline { 2 - 7 } & No. & $\%$ & No. & $\%$ & No. & $\%$ \\
\hline $1-10$ & 5 & 25.0 & 18 & 12.0 & 23 & 13.5 \\
\hline $11-20$ & 5 & 25.0 & 27 & 18.0 & 32 & 18.8 \\
\hline $21-30$ & 5 & 25.0 & 60 & 40.0 & 65 & 38.2 \\
\hline$>30$ & 5 & 25.0 & 45 & 30.0 & 50 & 29.5 \\
\hline Total & 20 & 100 & 150 & 100 & 170 & 100 \\
\hline
\end{tabular}

Table 3: Number of Computers in the Schools

Source: Field Survey, 2014

The data, as presented in Table 3, show that all the schools had computers in their computer laboratories and in some schools (67.7\%), there were 20 computers and more. Responses to the same question by Visual Arts students indicated that $18(12.0 \%)$ said they had between one and ten computers, 27(18.0\%) had between 11 and 20 computers, 60(40.0\%) had between 21 and 30, while 45(30.0\%) had 30 and more computers in their school laboratories. 


\subsection{Relevant Software on the Schools' Computers for Teaching and Learning of Visual Arts}

When the respondents were asked to indicate specifically what activities they used computers for $35.9 \%$ replied that they used the computers for drawing, painting and graphics formed only of the responses. Almost all the teachers (90.0\%) and 131(87.3\%) students indicated that Microsoft Office was the most popular software on the schools' computers. The respondents were then asked to indicate if the computers were accessible to them.

\begin{tabular}{|c|c|c|c|ccc|}
\hline Accessibility to & \multicolumn{2}{|c|}{ Teachers } & \multicolumn{3}{|c|}{ Students } & \multicolumn{2}{c|}{ Total } \\
\cline { 2 - 7 } Computers & No. & $\%$ & No. & $\%$ & No. & $\%$ \\
\hline They are always accessible & 10 & 50.0 & 65 & 43.3 & 75 & 44.1 \\
They are sometimes accessible & 6 & 30.0 & 54 & 36.0 & 60 & 35.3 \\
They are never accessible & 4 & 20.0 & 28 & 18.7 & 32 & 18.8 \\
\hline They are accessible for a fee & 0 & 0 & 3 & 2.0 & 3 & 1.8 \\
\hline Total & 20 & 100 & 150 & 100 & 170 & 100 \\
\hline
\end{tabular}

Table 4: Accessibility of School's Computers to Teachers and Students Source: Field Survey, 2014

According to the data in Table 4, 10 of the 20 teachers $(50.0 \%)$ indicated that the computers were always accessible and $65(43.3 \%)$ of the students confirmed that the computers were always accessible. However, four $(20.0 \%)$ teachers and $28(18.7 \%)$ students indicated that the schools' computers were never accessible after school

Figure 1 has the details of the responses on specific ways in which the computer had helped student's learning in Visual Arts.

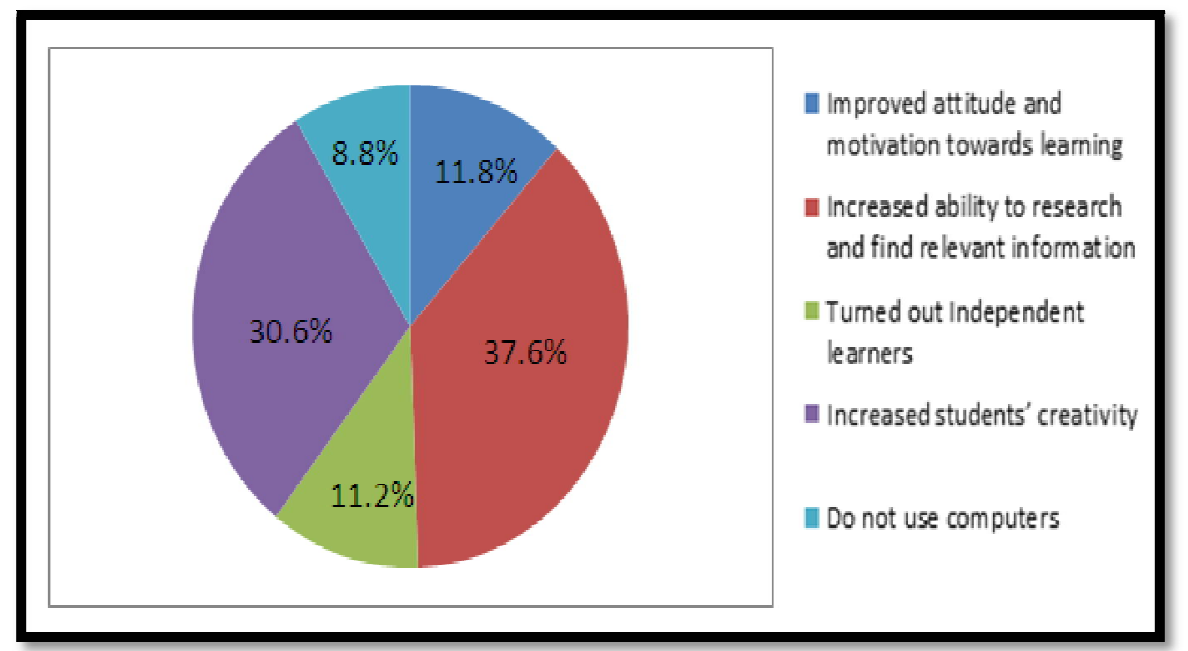

Figure 1: Ways in Which Computers Use Had Helped Students in Learning Source: Field Data, 2014

It can be realized from the data in Figure 1 that to 64 (37.6\%) of the respondents' computer use had increased ability to research and find relevant information. Another $52(30.6 \%)$, felt that computer had increased students' creativity. When the various groups are separated, it could be seen that six (30.0\%) teachers and 58(43.0\%) teachers indicated that computers had improved students' ability to research and find relevant information. On the other hand, nine $(45.0 \%)$ teachers, and also 43(31.8\%) students indicated that computers had increased their creativity.

\subsection{Attitude of Visual Arts Teachers and Students towards Computer Technology}

A series of questions were posed to find out the issue of attitudes of Visual Arts teachers and students towards computer technology and the responses of the results are presented in Tables and figures that follow.

\begin{tabular}{|c|c|c|c|ccc|}
\hline $\begin{array}{c}\text { Years of Experience } \\
\text { Computer Usage }\end{array}$ & $\begin{array}{c}\text { Teachers } \\
\text { No. } \%\end{array}$ & Students & \multicolumn{3}{|c|}{ Total } \\
No.\% & \multicolumn{3}{c|}{} \\
\hline Below one & 0 & 0 & 22 & 14.7 & 22 & 12.9 \\
\hline One to three & 2 & 10.0 & 30 & 20.0 & 32 & 18.8 \\
\hline Four to six & 5 & 25.0 & 38 & 25.3 & 43 & 25.3 \\
\hline Above six & 13 & 65.0 & 60 & 40.0 & 73 & 43.0 \\
\hline Total & 20 & 100 & 150 & 100 & 170 & 100 \\
\hline
\end{tabular}

Table 5: Respondents' Years of Experience in Computer Usage

Source: Field Survey, 2014 
With regard to the number of years of using computers, the overall results are that $68.3 \%$ of all the respondents had used the computer for more than six years. Most of the teachers (65.0\%) and (40.0) \% of the students had used computers for more than six years. As high as 22(14.7\%) of the students had less than one-year experience in computer usage.

3.5. Regularity of Usage of Computers by Respondents

The study also attempted to identify the regularity of usage of computers in the schools by the respondents.

\begin{tabular}{|c|c|c|c|c|c|c|}
\hline \multirow{2}{*}{$\begin{array}{c}\text { Regularity of } \\
\text { Computer Use }\end{array}$} & \multicolumn{2}{|c|}{ Teachers } & \multicolumn{2}{c|}{ Students } & \multicolumn{2}{c|}{ Total } \\
\cline { 2 - 7 } & No. & $\%$ & No. & $\%$ & No. & $\%$ \\
\hline Never & 3 & 15.0 & 23 & 15.3 & 26 & 15.3 \\
\hline Once a month & 4 & 20.0 & 27 & 18.0 & 31 & 18.2 \\
\hline Once a week & 4 & 20.0 & 83 & 55.3 & 87 & 51.2 \\
\hline Thrice a week & 4 & 20.0 & 15 & 10.0 & 19 & 11.2 \\
\hline Everyday & 5 & 25.0 & 2 & 1.3 & 7 & 4.1 \\
\hline Total & 20 & 100 & 150 & 100 & 170 & 100 \\
\hline
\end{tabular}

Table 6: Regularity of Computers Usage by Respondents

Source: Field Survey, 2014

The overall picture was that only seven of the 170 respondents used the computer every day, and as high as 26 never used the computer. The results of the analysis presented in Table 6 indicate that among the teachers, five (25.0\%) used the computer every day, four (20.0\%) used the computer three times a week, four used computers once a week and another four used computers once a month. Unfortunately, three $(15.0 \%)$ of the teachers never used the computer in the school. Concerning how often students used the computers in the school, the responses indicated that 83(55.3\%) used the computer once a week, 15(10.0\%) used the computer at least once a week and $27(18.0 \%)$ used the computer once a month. Only two (1.3\%) of the 150 students used the computer everyday of the week, with 23(15.3\%) indicating that they never used the computers in the school.

\subsection{Use of Computers in Teaching and Learning Visual Arts}

The study was specifically to find out the use of computers by Visual Arts teachers and students so they were asked to indicate specifically what activities they used computers for. This question was aimed at finding out whether they used the computers for Visual Arts activities at all. Table 7 presents the results.

\begin{tabular}{|c|cc|cc|cc|}
\hline Use of Computers & \multicolumn{2}{|c|}{ Teachers } & \multicolumn{2}{|c|}{ Students } & \multicolumn{2}{c|}{ Total } \\
& \multicolumn{1}{|c|}{ No. } & \% & \multicolumn{2}{|c|}{ No. } & \% & \multicolumn{2}{c|}{ No. } & $\mathbf{\%}$ \\
\hline Access news and info & 4 & 20.0 & 74 & 49.3 & 78 & 45.9 \\
Draw, paint and graphics & 16 & 80.0 & 45 & 30.0 & 61 & 35.9 \\
Word processing & 0 & 0 & 14 & 9.3 & 14 & 8.2 \\
Use spread software & 0 & 0 & 11 & 7.4 & 11 & 6.4 \\
Computer programming & 0 & 0 & 4 & 2.7 & 4 & 2.4 \\
Create/ maintain website & 0 & 0 & 2 & 1.3 & 2 & 1.2 \\
\hline Total & 20 & 100 & 150 & 100 & 170 & 100 \\
\hline
\end{tabular}

Table 7: Activities Computers Were Used for by Respondents

Source: Field Survey, 2014

A critical examination of the data in Table 7 reveals that the activities computers in the selected schools were used for were mostly for accessing news and information by 78(45.9\%) of both staff and students. The same trend is observed as $20(5.0 \%)$ of the teachers and $74(49.3 \%)$ of the students. The next activity the computers in the schools were used for is to draw, paint and graphics as by $16(80 \%)$ of the teachers and $45(30.0 \%)$ of the students. 


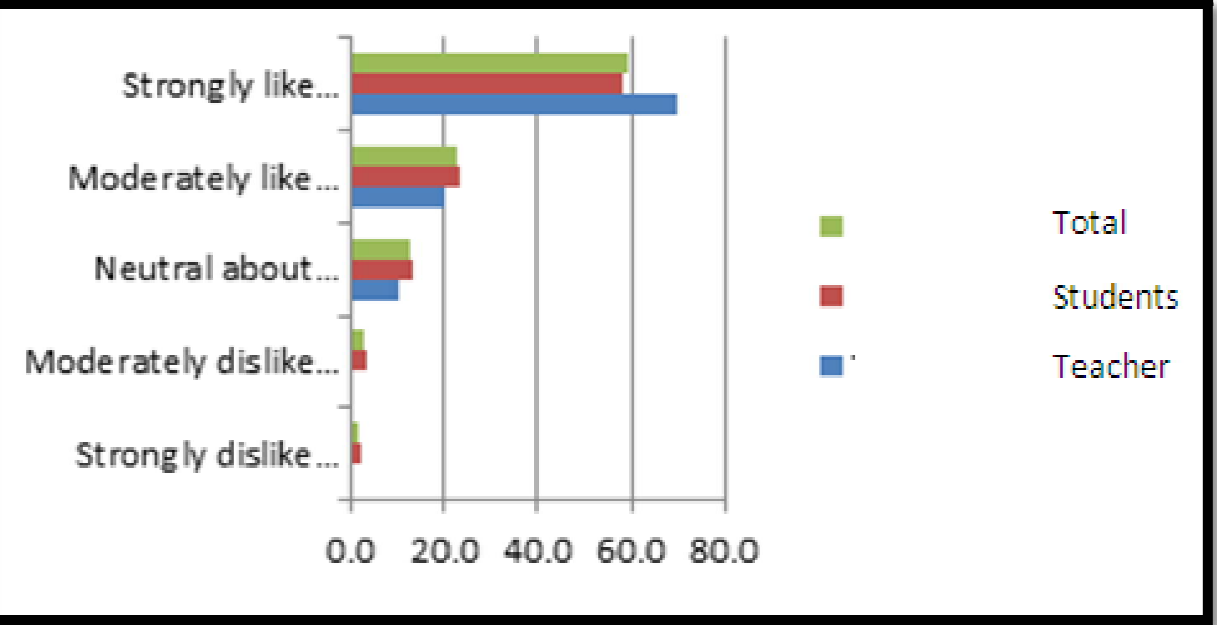

Figure 2: Attitude of Teachers and Students towards Computers Source: Field Survey, 2014

The attitude of teachers regarding the use of computer technology, as shown in the data in Figure 2, indicate that $14(70.0 \%)$ teachers strongly liked computers, four (20.0\%) moderately liked computer and none of them strongly disliked only computers. The results on students' attitude regarding the use of computer technology in Visual Arts revealed that the most of the students $87(58 \%)$ strongly liked computers, 35(23.3\%) moderately liked computers and only eight (5.3\%) disliked computers.

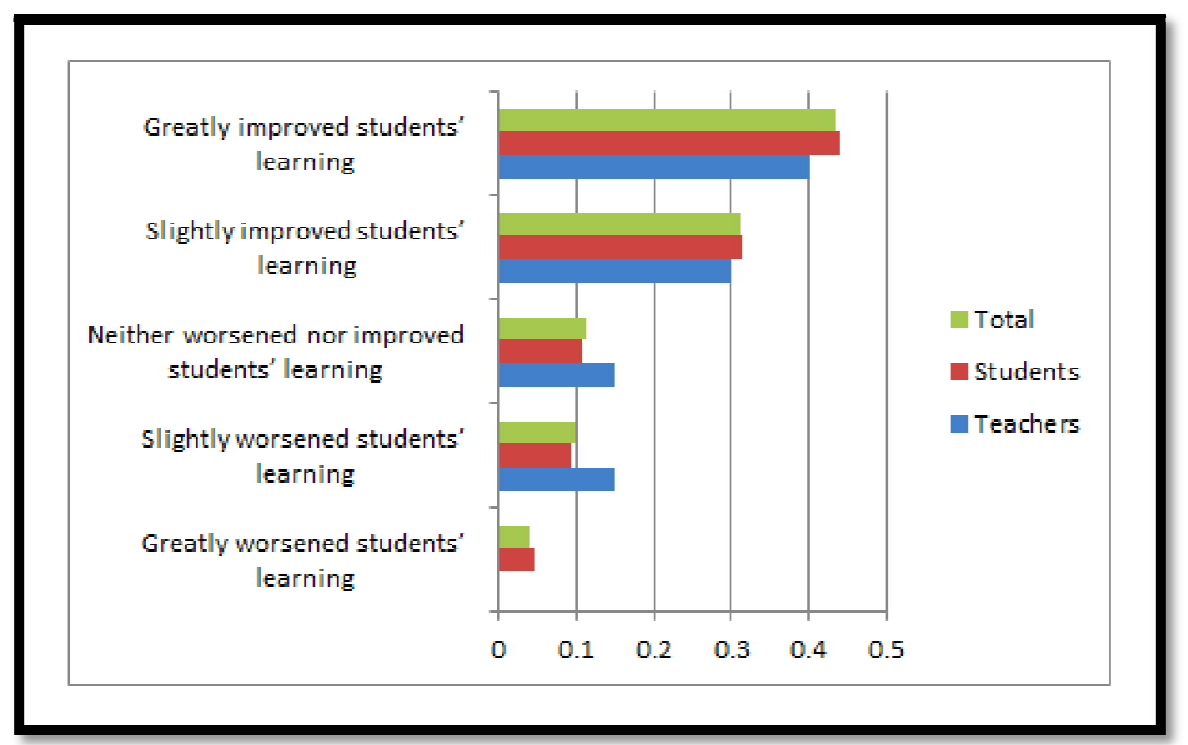

Figure 3: Respondents' Views on Effects of Computers on Student's Learning Source: Field Survey, 2014

The results, as shown in Figure3, indicate that in the view of 43.5\%) of the teachers' computers and the students, computer us had greatly improved students' learning. About a third (31.2\%) of them felt that computers had slightly improved students' learning, $11.2 \%$ were neutral, $10.0 \%$ felt and the remaining three (15.0\%) believed that computers had worsened students' learning. Similarly, 113(75.3\%) of the students held the view that computers had improved students learning, $16(10.7 \%)$ were neutral about the effect of computers on students' learning, while 21(14.0\%) students indicated that computers had worsened students' learning. The findings on respondents' views on effects of computers on student's learning indicate that Visual Arts teachers and students in the sample had a high overall mean score of 4.14 and 4.20 respectively.

\subsection{Challenges Faced In the Use of Computers in Teaching and Learning of Visual Arts}

This section presents the challenges and concerns teachers and students faced when using computers in their schools and it starts with the respondents' views. 


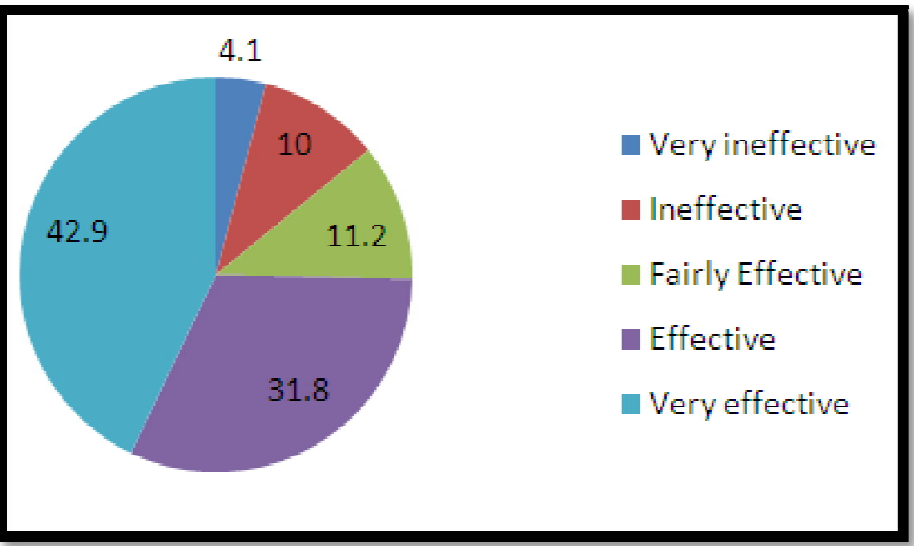

Figure 4: Respondents' Views on the Effectiveness of Computers

Source: Field Survey, 2014

It can be deduced from Figure 4that $42.9 \%$ of the respondents found computer use in the teaching and learning of Visual Arts in the schools to be effective. Nearly $31.8 \%$ of the respondents found computer use to be effective.

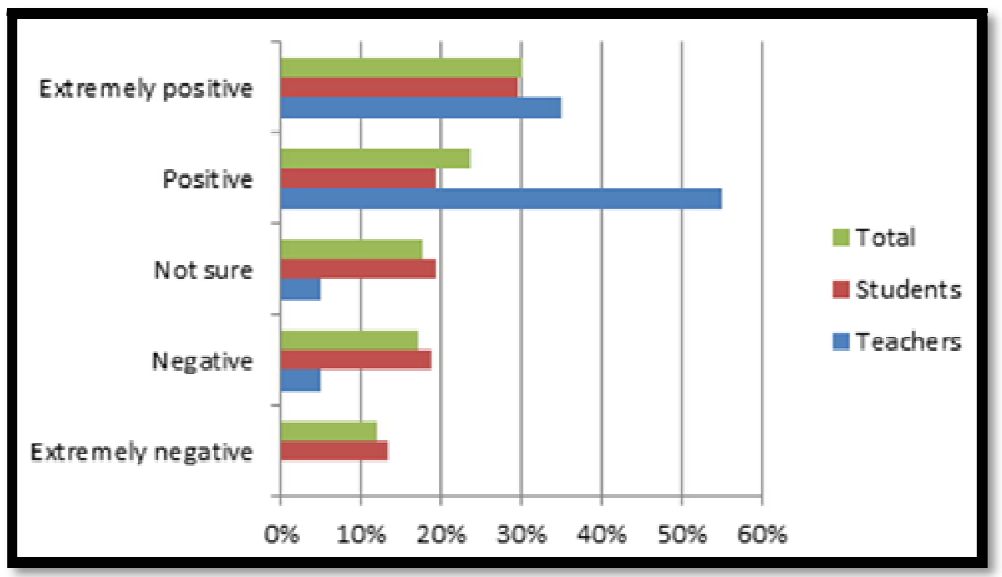

Figure 5: Overall Impact of Computers in School

Source: Field Survey, 2014

The overall impact of computers in the schools was considered by $53.5 \%$ of the respondents as positive, with amen of 3.43 . Eighteen (90.0\%) of the teachers and $48.7 \%$ of the students considered the impact of computers in the teaching and learning of Visual Arts as positive (Figure 5), with a mean of 4.20 for teachers and 3.19 for students.

The next section deals with main challenges the respondents faced in the use of computers for teaching and learning Visual Arts in their schools.

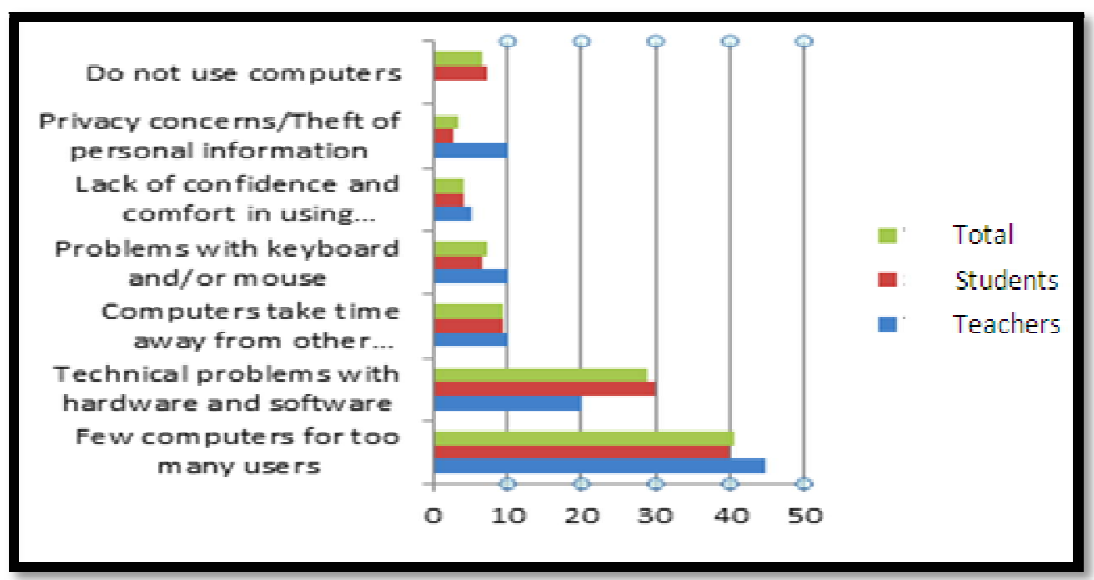

Figure 6: Main Challenges Respondents Faced When Using

Computers at School

Source: Field Survey, 2014

The data presented in Figure 6 show that the main challenge of $40.6 \%$ of the respondents was few computers for several users. Technical problems with hardware and software were the next challenge given by $28.8 \%$ of the teachers and students. 


\section{Discussion}

The demographic data obtained from the analysis of the teachers' ages found the average age of the teachers was 29 years with the youngest being 20 years and the oldest 48 years. The youthfulness of the teachers' age suggests their desire to have positive attitude towards the use of computers in the teaching of Visual Arts.The results of ages of the students also indicated that they were mostly teenagers and as a group, they are found to be very interested and mostly found in internet cafes. The analysis of the gender of the respondents indicated that the majority of Visual Arts teachers in the selected schools in the Cape Coast Metropolis were males and that their interest in using the computer should be higher since males are more inclined to technology than their female counterparts. The results of the gender of the students also revealed that the male students in the Visual Arts programme were slightly more than the female students in the sample from Cape Coast Metropolis public SHS. However, the percentage range is not as wide as that of the teachers. This result implies that more males are inclined towards the study of Visual Artsthan females and further indicates that male have positive attitude towards visual arts and the use of ICT. It can also be attributed to the fact that the population of students is definitely more than teachers and that many of them drop off and enter into different occupations in life and only a few may be teachers of Visual Arts.

On the years of experience in computer use, it can be said that the teachers had a relatively rich experience in the computer usage. This revelation on the computer usage was not beyond is expectation since their ages showed that most of the teachers in the sample were relatively young. A high percentage of students had also had long exposures to computers.

It was discouraging that 22 of the students had less than one-year experience in computer use. It was possible that they were the students from poor homes and or rural communities where there might be no electricity and/ or computers. Their parents might also not have resources to buy them computers, thus the experiences they had would be the only ones they had from their enrolment in the metropolitan schools.

On facilities/ resources available in the selected schools for computer use, the respondents indicated that the schools had computer laboratories but having the laboratories was not enough, the number of computers in the schools was the most important issue. Although all the school had computers, they were for the whole school and not solely for the teaching and learning of Visual Arts. Since the important variable of ICTs integration in schools is availability of ICT infrastructure. Also, the numerous factors identified as hindrances to the use of ICTs in high schools by Pelgrum (2001) included insufficient number of computers and ICT infrastructure. The number of computers in the schools, all of which have student populations not less than 500, are definitely inadequate and is likely to hamper the smooth understanding of the ICT programme.

On the regularity of usage of computers by respondents, it is clear therefore that the use of computers among teachers and students of Visual Arts in the sample was quite low. The overall picture was that only seven of the 170 respondents used the computer every day, and as high as 26 never used the computer. The fact that computer use was found to be low made an inquiry into accessibility of the schools' computers to teachers and students after school hours very relevant. The results attested to the fact that less than half of the teachers and students (44.1\%) had unrestricted access to the schools' computers after school. The physical accessibility was acceptable but some conditions of inadequate numbers of computers to the number of students who needed to use them as well as the available time made them difficult.

The fact that out of the 170 teachers and students used computer mainly for accessing news and information and only $35.9 \%$, used computer for drawing, painting and graphics showed that very few of the students in the sample used computers for Visual Arts purposes. The reason could be attributed to lack of appropriate skills in the area. This finding confirms the belief by ICT researchers such as Dusick (1998) and Ertmer et al., (1999) that a successful implementation of ICT is often impeded by both external barriers (including lack of access to computers and software, inadequate technical training), and internal barriers, which also borders on lack of relevance of computer technology resources in teaching have revealed.

There was a need to ask the respondents to indicate the relevant software on the computers for teaching and learning Visual Arts in their schools. The reason was that when they were asked to indicate specifically what activities they used computers for, drawing, painting and graphics formed only $35.9 \%$ of the responses. The general impression is that most teachers and students had skills in the use of Microsoft Office and not skills in designing software such as CorelDraw and Photoshop. The reason why Microsoft Office appeared to be the most relevant software on the school's computers is not surprising. It is a fact that all over the country most of the training people receive from both public and private institutions as well as private internet cafes is all in Microsoft Office. It can therefore be deduced that most of the teachers did not have skills in other designing software. Another major reason is that there is no computer laboratory dedicated solely to Visual Arts or any subject-related course in any public school in the region. Most schools have a common computer laboratory for the all students in the schools, regardless of the number of programmes. Hence, general software/ programmes were installed for general purposes and not for like Visual Arts. This finding further confirms the belief by Dusick (1998) and Ertmer et al., (1999) certain external as well as internal barriers, which border lack of access to computers and software, inadequate technical training and lack of relevance of computer technology resources in teaching do hinder successful ICT implementation in schools.

It is evident from the overall results that $59.5 \%$ of the respondents, strongly liked computers in general and would want to continue using computers in teaching and learning. This result, with a high mean score of 4.60 for teachers and 4.32 for students, indicated that despite inadequacy of computers and consequently many students failing to use the computer technology for Visual Arts education, the students in the sample had positive attitude towards the use of computer technology. This meant that if they had the opportunity to use the computers they would gladly do so. 
In general, the impact of computers on both teachers and students was declared as effective by $74.7 \%$ of them. The impact of computers on both teachers and students scored a mean of 3.95 and 3.97 respectively, buttressing the fact that the impact of computers was thought of as very effective by the respondents. It will be heart-warming if the assessment was based on how it has changed the way teachers taught and not the effectiveness based on the use of computers for the social media. It is, however important to note that $51.3 \%$, being more than half of the student, were either not sure of the impact of computers or were of the view that the impact was negative, probably because they did not have a good use of the computers for learning Visual Arts. This is a great set-back in the use of computers for teaching and learning.

On the realization that $74.7 \%$ of the respondents held the view that computers worsened improved teaching and learning, further probing was done. It was revealed that in the view of those who claimed computers had not improved learning was based on the fact that students were using computers mainly for accessing social media and films and so they did not have enough time to learn.

In the overall responses from the entire sample the main concern was too many people but not enough computers given by $40.6 \%$ of the respondents, followed technical problems with hardware and software and the fact that computers took time away from other educational activities were given by $75(44.1 \%)$ and 36(21.2\%) of both teachers and students respectively. Further investigation into the problems associated with the software and hardware use indicated that installation of software on the computer was the major problem with the software, which resulted mainly from lack of technical support from qualified technicians with adequate knowledge in computer hardware.The time element was not surprising because the challenges of hardware and software will result in a lot of time wasted by anyone who got access to any of the computers.

\section{Conclusions}

In the 10 selected Senior High Schools in the Cape Coast Metropolis that offered Visual Arts, there were more males than female teachers and students. The overall results on computer usage showed that $68.3 \%$ of the respondents (teachers and students) had six years experience in computer usage.

All Senior High Schools in Cape Coast that offer Visual Arts in the sample had between 20 and 50 computers in their school laboratories. However, the computers were grossly inadequate as compared to the number of staffs, both teaching and non-teaching and students. Less than $50.0 \%$ of the staff and students had unrestricted access to the school computers and 26 had never used computers.

Though the majority of teachers and students had skills in the use of computers, only $35.9 \%$ used the computers for computers for subject-related courses.

Most of the teachers (70.0\%) and students (58.9\%) had positive attitude towards computers Visual Arts teaching and learning. The majority (74.7\%) of the teachers and students indicated that the overall impact of computers on students learning was positive and that it had improved teaching and learning of Visual Arts and would continue to use computers in teaching and learning. On the other hand, not all teachers felt comfortable and confident that they could integrate computer technology resources into their teaching practices.

The major challenge reported by $40.6 \%$ of the Visual Arts teachers and students was inadequate number of computers. Technical problems with hardware and software were reported. These were associated with software installation and hardware repairs. Some other challenges were lack of confidence, lack of competence and lack of access to computer resource.

\section{Recommendations}

Every effort should be made by the government, school management, Board of Governors, old students and NGOs to construct computer big laboratories and equip them with computers and the relevant software for the various programmes the schools offer.

Computer technology programmes offered on campus should be tailored to specific academic disciplines. For instance, Visual Arts students can be taught CorelDraw and Photoshop

The need for government policies to take care of issues such as class size, training of teachers in ICT funding, provision of ICT facilities and inclusion into the curriculum.

Headmasters/ headmistresses should allow teachers and students access to ICT after school hours in order to have more time with the computer technology.

Curriculum planners should review Visual Arts curriculum to reflect on computer technology integration into the teaching and learning of the course.

Finally, knowledge and training alone may not be enough for the use of computer technology resources in teaching and learning. A better integration of computer technology resources into the curriculum may help in eliminating such factors as time that prevents teachers and students from using these resources in supplementing their teaching and learning.

\subsection{Areas for Future Research}

The results indicate that much attention ought to be given to this area of research. It is therefore recommended that future research in this direction consider private senior high schools in order to establish a more comprehensive conclusion. 


\section{References}

i. Albirini, A. (2006). Teachers' attitudes towards information and computer technologies: The case of Syrian EFL teachers. Computer and Education, 47, 373-398.

ii. Amedahe, F. K. (2002). Fundamentals of educational research methods. Mimeograph. Cape Coast: University of Cape Coast

iii. Bamford, A. (2006). The wow factor: Global research compendium on the impact of the arts in education. Berlin: Waxmann Verlag.

iv. Bransford, J., Brown, A. L., \& Cocking, R. R. (Eds.). (2000). How people learn: Brain, mind, experience, and school (2nd ed.)

v. Crowe, B. (1988). Computers in secondary school art curriculum: Painting a picture of effective teaching. Paper presented at the annual meeting of the Mid-South Educational Research Association, Lexington.

vi. Dankwa, W. A. (1997). SchoolNet: A catalyst for transforming education in Ghana. Retrieved on 20th February, 2014 fromhttp:/ / www.isoc.org/ isoc/ whatis/ conferences/ inet/ 96/ proceedings/ c6/ c6_1.htm.

vii. Delacruz, E. (2004). Teachers' working conditions and the unmet promise of technology. Studies in Art Education, 46 (1), 6 - 20.

viii. Duncan, P. (1997). Art education and information technology. Journal of the Australian Institute of Art Education, $20(3), 47-50$

ix. Dusick, D. M. (1998). What social cognitive factors influence faculty members' use of computers for teaching? A literature review. Journal of Research on Computing in Education, 31(2), 123 - 137.

x. Ely, D. P. (1993). Computers in schools and universities in the United States of America. Educational Technology, 33(9), 53 - 57.

xi. Ertmer, P. A., Addison, P., Lane, M., Ross, E., \& Woods, D. (1999). Examining teachers' beliefs about the role of technology in the elementary classroom. Journal of Research on Computing in Education, 32 (1), 54-72. Retrieved November 2, 2013 from EBSCO Host.

xii. Fraenkel, J. R., \&Wallen, N. E. (2006). How to design and evaluate research in education. McGraw-Hill: Boston

xiii. Government of Ghana. (2003). The Ghana ICT for Accelerated Development (ICT4AD) Policy. Retrieved on 2/ 15/ 11 at Government of Ghana (2005). Government of Ghana Ministerial ICT Policy Statement: Accra: NBS Multimedia

xiv. Grimus, M. (2000). ICT and multimedia in the primary school. Paper presented at the 16th conference on educational uses of information and communication technologies, Beijing, China.

xv. Harvey, W. B. (1993). Educational technology and Third World development, Journal of Educational Technology Systems, 11(3), 265-270.

xvi. Henning, G. (2000). Introducing digital technologies into the year 9/ 10 visual arts program: Cooperative learning in action. Australian Art Education, 23(2), 37-41.

xvii. Loveless, A. (2003). Making a difference? An evaluation of professional knowledge and pedagogy in art and ICT.Journal of Art and Design Education, 22 (2), 145 - 154.

xviii. Matthew, K., Callaway, R., Letendre, C., Kimbell-Lopez, K., \& Stephens, E. (2002). Adoption of information communication technology by teacher educators: one-on-one coaching. Journal of Information Technology Teacher for Education.11(1), 45 - 61.

xix. Mooij, T., \&Smeets, E. (2001). Modelling and supporting ICT implementation in secondary schools. Computers and Education, 36, 265-28.

xx. Parthemore, J. (2003). A secondary school computer laboratory in rural Brong Ahafo: A case study reflection on the future of secondary school computer literacy and computer-based distance education in Ghana. [Online]. Retrieved from http:/ / www.wess.edu.gh/ lab/ reports/ papers.pdf.on February 20, 2015.

xxi. Rogers, P. (1995). Towards a language of computer art: When paint isn't paint. Art Education, 9, 17-33.

xxii. Taylor, S. (1999). A computer convert's story. EQ Australia. [Verified 22 Dec 2007]

xxiii. http:/ / www1 .curriculum.edu.au.eq/archive/ prior2002/ eq 99/ taylor.htm

xxiv. Tella, A. (2007). Teachers' perception of the contribution of ICT to pupils' performance. Retrieved from http:/ / cis.unilorin.edu.ng/ index.php/ 2014-06-09-34-59/ library -and-information-sciences/ 113-dr-tellaadeyinka.

xxv. Tesfay, (2008). How to integrate information and communications technology.

xxvi. http:// www.grin.com/ en/ e-book/ 200492/ howto-integrate-information-and-communications-technology.

xxvii. Wang, L. (2002). How teachers use computers in instructional practice. Four examples in Americans schools. Journal Art and Design Education 21(2), 154 - 163.

xxviii. Wikipedia Free Encyclopaedia Corel draw/Photoshop. Retrieved from https:// en.wikipedia.org/wiki/ Adobe on 31st August 2016.

xxix. Wood, J. (2004). Open minds and a sense of adventure: How teachers of art and design approach technology. The International Journal of Art and Design Education, 23(2), 179 - 191.

xxx. Yelland, N. (2001). Teaching and learning with information and communication technologies (ICT) for numeracy in the early childhood and primary years of schooling. Australia: Department of Education, Training and Youth Affairs

xxxi. Yildirim, S. (2007). Current utilization of ICT in Turkish basic schools: A review of teacher's ICT use and barriers to integration. International Journal of Instructional Media, 34 (2), 171 - 186. 